\title{
Conhecendo o passado: relações entre a literatura brasileira contemporânea e a escrita da história
}

\author{
Knowing the past: relations between contemporary Brazilian literature \\ and the writing of history
}

\author{
MATEUS ROBASKI TIMM \\ Pontifícia Universidade Católica do Rio Grande do Sul. Porto Alegre, RS, Brasil.
} a

\begin{abstract}
Resumo: A compreensão que a capacidade de aportar conhecimento sobre o passado não é exclusiva dos textos historiográficos proporcionou à literatura um novo estatuto, que lhe assegura pertinência epistemológica para recontar o passado. Neste artigo são analisadas diferentes formas em que o discurso literário configura o tempo histórico. Num primeiro momento, a potencialidade da literatura em rever criticamente os traumas do passado visa mostrar como é necessário que mais escritores se debrucem sobre situações terríveis como a escravidão e a ditadura para que estes traumas sejam passados a limpo. Na segunda parte, versões diferentes de relacionar a literatura com a história são propostas, através de uma leitura dos romances pelo viés da história das mentalidades, da história dos fatos públicos, mas também ao fazer do escritor personagem de ficção. Na última parte, a configuração ficcional do passado que é quase presente permite perceber algumas constantes que estão relacionadas com a contemporaneidade.

Palavras-chave: Literatura e história; Literatura brasileira contemporânea; Escrita da história.
\end{abstract}

\begin{abstract}
The understanding that the ability to bring knowledge about the past is not unique to the historiographical texts provided the literature with a new statute, which assures epistemological relevance to retell the past. In this article we analyze different ways in which literary discourse configures historical time. First, the potential of literature to critically review the traumas of the past seeks to show how it is necessary for more writers to dwell on terrible situations such as slavery and dictatorship so that these traumas are cleared up. In the second part, different versions of relating literature to history are proposed, through a reading of the novels by the bias of the history of mentalities, of the history of public facts, but also by making the writer a fictional character. In the last part, the fictional configuration of the past that is almost present allows one to perceive some constants that are related to contemporaneity.
\end{abstract}

Keywords: Literature and history; Contemporary Brazilian literature; History writing.

As maneiras de fornecer um meio de acesso ao passado consistem num dos mais belos problemas no campo das ciências humanas. No texto intitulado "Como conhecemos o passado", David Lowenthal reflete sobre este inquietante dilema, partindo do pressuposto que a escrita da história é sempre inferior à complexidade do tempo passado. Esta condição assimétrica resulta na impossibilidade de recontar substancialmente o que ocorreu: nenhum discurso histórico dá conta de trazer o passado de volta para o presente, tal como ocorreu.

Discurso histórico e passado não são instâncias equivalentes. Isto quer dizer que nenhuma linguagem configurada discursivamente é capaz de abranger completamente o que já aconteceu. Com a perda da supremacia da disciplina da história, enquanto instância única para recontar o passado, a literatura vem sendo também considerada como discurso eficaz para escrever a história. Na opinião de David Lowenthal, história e passado não podem ser confundidos devido a três fatores: 1) o conteúdo do passado é virtualmente infinito e nenhum relato consegue recuperá-lo totalmente por mais minuciosa que seja a escrita do discurso histórico; 2) um discurso verbal não recupera o tempo passado tal e qual, porque o passado não foi um relato, mas um conjunto de acontecimentos e situações. Por conta disto, "a narrativa histórica não é um retrato do que aconteceu, mas uma 
história sobre o que aconteceu" (LOWENTHAL, 1998, p. 111). A configuração narrativa faz com que o aceite ou a rejeição de determinado relato histórico esteja assegurado apenas pela plausibilidade e pela confiabilidade da sua relação com outros discursos sobre o passado reconhecidos como portadores de um conteúdo confiável; 3) a escrita do conhecimento histórico, por possuir um enunciador da narrativa, invariavelmente passa pela subjetividade humana, pois existe um intérprete mediando os acontecimentos passados para a recepção de tais fatos. Consequentemente, "a perspectiva e as predileções do narrador moldam sua escolha e sua utilização dos materiais históricos; [...] nenhum observador, por mais imerso no passado, pode despojar-se de seus conhecimentos e suposições" (LOWENTHAL, 1998, p. 113).

Com a quebra da hegemonia do relato historiográfico enquanto fonte incontestável para acessarmos o passado, a ficção ganha força enquanto componente importante para o entendimento histórico. A literatura pode trabalhar com o tempo passado de diversas formas. Assim, algumas obras ficcionais utilizam a história como pano de fundo do enredo; outras transformam pessoas reais em personagens romanceados, inserindo episódios inventados ou mantendo fatos verdadeiros; também há obras que distorcem, acrescentam ou omitem acontecimentos históricos em prol da qualidade estética da ficção. No entanto, a revitalização da vertente realista na literatura brasileira contemporânea, aponta para o desejo dos escritores em buscar uma semelhança com o tempo passado. Por conseguinte, alguns romances publicados nos últimos anos ajudam os leitores a conhecerem e a refletirem sobre o que já ocorreu historicamente, mesmo que o passado posto na ficção seja próximo do século XXI.

De maneira semelhante à literatura, a história não existe enquanto discurso verdadeiro do tempo humano, sendo os seus discursos nada mais que ficções possuindo diferentes graus de plausibilidade. O papel do historiador de esclarecer, ordenar e elucidar os fatos pode ser compartilhado ao do romancista, que também possui um papel importante no fornecimento de visões sobre o tempo passado. Este viés reflexivo permite perceber quanto a diluição das fronteiras entre os campos da história e da literatura corrobora para a ampliação de visões pertinentes sobre o passado, pois a capacidade de fornecer uma visão plausível do tempo passa pela compreensão de que a narrativa da história desenvolvese de maneira semelhante à narrativa ficcional:

A indistinção entre os limites da história e da ficção deveria tornar os historiadores mais humildes, advertindo-os do quão fragmentária e oblíqua deve ser a sua visão do passado; também deveria alertá-los para novas possibilidades. Abandonando uma epistemologia positivista, eles poderiam... revelar um âmbito mais amplo de verdades históricas. Poderiam até mesmo reconhecer a força da verdade da ficção literária (LOWENTHAL, 1998, p. 146).

Portanto, por conta disto, é possível confiar na força epistemológica da literatura brasileira contemporânea no trabalho de escrita da história. Os séculos XX e XXI aparecem de diferentes formas no corpus de oito romances que será analisado neste trabalho. Assim, a primeira parte abordará alguns traumas do passado nacional, como a escravidão e a ditadura. Num segundo momento, duas concepções diversas de perceber a história são focalizadas para a leitura dos romances Machado e $A$ vida invisivel de Eurídice Gusmão: no primeiro, o passado é visto pelos acontecimentos de ordem pública e na recriação metaficcional de Machado de Assis; no segundo, a história das mentalidades ajuda a compreender esta vida invisível de Eurídice Gusmão. Na terceira parte do trabalho será abordado como o passado que é quase presente aparece em três romances da literatura brasileira contemporânea.

\section{Traumas da história na literatura brasileira contemporânea}

A literatura possui a potencialidade ontológica de amparar os mais diversos discursos, sendo assim possível se valer da linguagem literária para trabalhar com fatos traumáticos do passado histórico brasileiro. Este tem sido um viés privilegiado pelos escritores contemporâneos, que buscam refletir sobre as experiências de dor e sofrimento presentes na história nacional. Tal atitude evidencia que os romances contemporâneos não estão ancorados somente num passado próximo; pelo contrário, as mais diversas temporalidades são configuradas na criação dos enredos literários.

O romance Ponciá Vicêncio (2003) de Conceição Evaristo narra a trajetória da família Vicêncio, composta por descendentes de escravizados. O enredo deste romance se passa nas primeiras décadas do século XX e desvela a dificuldade existencial dos negros, mesmo no período posterior à Lei Áurea. O compartilhamento de vivências materiais e psicológicas humilhantes ou degradantes acaba configurando uma condição existencial vilipendiada. Um exemplo desta humanidade vilipendiada é o fato de o sobrenome Vicêncio vir do Coronel Vicêncio, que escravizara os antepassados da família de Ponciá. Desgraça histórica, a vergonha de um nome que marca pelo horror indelével da escravidão faz com que Ponciá questione ser nomeada Vicêncio, pela humilhação de carregar num traço identitário a herança de um passado terrível: 
Ponciá, na verdade, simboliza o espaço e o tempo de uma história contundida, de exclusão e subserviência que foi imposta ao povo afro-descendente brasileiro. Ficção e realidade se imbricam nas camadas narrativas, todavia o que vai aflorando é uma escrita tensa e densa de dizeres sofridos, numa lírica contundente (SILVA, 2007, p. 73).

As formas de exploração pelos antigos senhores de escravos ou pelos modernos patrões acabam reificando a humanidade dos negros. Por conta da sua família ser equiparada a um bem material, num acesso de fúria, que também pode ter sido uma epifania da sua condição vilipendiada, o avô de Ponciá mata a mulher e tenta se suicidar, após descobrir que seus filhos foram vendidos. Este tipo de ação foi uma prática histórica frequente da comunidade de negros escravizados, tendo por objetivo escapar da sua condição humilhante. Assim, o avô de Ponciá não chega a morrer, mas acaba decepando uma mão neste ato desesperado. Eis o trecho:

Três ou quatro dos seus, nascidos do "Ventre Livre", entretanto, como muitos outros, tinham sido vendidos. Numa noite, o desespero venceu. Vô Vicêncio matou a mulher e tentou acabar com a própria vida. Armado com a mesma foice que lançara contra a mulher, começou a se autoflagelar decepando a mão. Acudido, é impedido de continuar o intento. Estava louco, chorando e rindo (EVARISTO, 2017, p.44).

Esta passagem mostra como, mesmo com a mudança do sistema econômico baseado na mão de obra escrava para o trabalho livre, a condição dos ex-escravizados não mudou em essência. O pai de Ponciá, não obstante já ser filho de ex-escravos, cresceu na fazenda levando a mesma vida dos avôs escravizados: "era pajem do sinhô-moço. Tinha a obrigação de brincar com ele. Era o cavalo em que o mocinho galopava sonhando conhecer todas as terras do pai" (EVARISTO, 2017, p. 17). Esta condição áspera da existência do pai de Ponciá, que ativa uma intertextualidade com uma cena de Memórias Póstumas de Brás Cubas, é reiterada na narração de mais atos racistas:

Pajem do sinhô-moço, escravo do sinhô-moço, tudo do sinhô-moço, nada do sinhô-moço. Um dia o coronelzinho, que já sabia ler, ficou curioso para ver se negro aprendia os sinais, as letras do branco, e começou a ensinar o pai de Ponciá. O menino respondeu logo ao ensinamento do distraído mestre. Em pouco tempo reconhecia todas as letras. Quando sinhô-moço certificou-se de que o negro aprendia, parou a brincadeira (EVARISTO, 2017, p. 17).

Estas práticas de dominação convergem com o conceito de violência simbólica, cunhado pelo sociólogo francês Pierre Bourdieu. Tal tipo de violência consiste na execução de ações que não são violência física, mas que causam danos morais e psicológicos. Esta prática incide na coação que se apoia numa imposição, seja econômica, social, cultural, etc. A recorrência da violência simbólica induz o indivíduo a se posicionar no espaço social seguindo critérios e padrões do discurso dominante. Deste modo, outro exemplo de violência simbólica, no romance Ponciá Vicêncio, pode ser encontrado na cena em que um delegado diz a Luandi, irmão de Ponciá, que todo negro é ladrão: "E que Luandi não levasse a mal o que ele [o delegado] ia dizer, mas quase todo negro era vagabundo, baderneiro, ladrão e com propensão ao crime [...], Luandi continuava calmo, parado, longe, como se ao delegado não estivesse ouvindo" (EVARISTO, 2017, p. 102). A configuração literária desta condição existencial vilipendiada dos negros brasileiros consiste numa prática crítica proposta por Conceição Evaristo para expor tamanha situação degradante. É por este viés que Assunção de Maria Souza e Silva compreende Ponciá Vicêncio:

O romance de Conceição Evaristo, pela sua atualidade e inserido na realidade étnico-racial brasileira, instiganos a refletir sobre a situação da população afrobrasileira, leva-nos a olhar para a outra face, silenciada e ocultada da história do Brasil, e desmitifica, no âmbito da literatura brasileira, determinadas cristalizações, resultantes de um discurso dominante do mito da democracia racial (SILVA, 2007, p. 73).

Assim, em Ponciá Vicêncio é narrada a passagem da hierarquia senhor da plantação/escravo, para a nova dicotomia classe dominante/sujeitos subalternos. A manutenção da inferioridade e da exclusão do negro não é outra coisa que uma suposta dissimetria fundamental, mas que na verdade foi historicamente construída: a que tem de um lado o sujeito e de outro o objeto, ou então o agente e o instrumento. $\mathrm{O}$ mérito do romance de Conceição Evaristo é expor criticamente estas práticas de dominação, muitas delas até então sem voz dentro da literatura ou da história brasileira.

Outro trauma que a ficção brasileira contemporânea recupera é o tempo sombrio da ditadura militar. RioParis-Rio (2016), de Luciana Hidalgo e $O$ amor dos homens avulsos (2016), de Victor Heringer são textos que de alguma maneira abordam os desmandos da ditadura militar. O uso crítico da memória aparece como ato político através da construção ficcional incisiva deste período áspero da história nacional, além de trazer para o presente esta carga traumática que ainda não foi passada a limpo.

Rio-Paris-Rio conta a paixão de um jovem casal exilado em Paris devido ao estado de exceção implantado 
no Brasil com a ditadura militar. Maria deixa o país, pois o seu avô é um dos militares que sustentam o golpe. Arthur vai à França para evitar a possível repetição do destino do seu pai comunista, que após ser torturado pelos agentes da ditadura, acaba tornando-se paranoico.

O romance expõe uma série de acontecimentos que remetem ao discurso historiográfico, embora estejam configurados como ficção, por exemplo, a personagem Marechal, que sai do Brasil para não ser preso, e, em Paris, busca outros exilados para formar uma espécie de resistência à ditadura. Além disso, a potencialidade da criação artística permite que a condição imposta pelo golpe ditatorial seja pensada criticamente pela personagem Maria. De uma maneira mais sensível que o discurso historiográfico mais clássico, a situação do Brasil é exposta para o seu amigo da classe alta parisiense:

\begin{abstract}
Vocês têm sorte, Luc, de estarem aqui na França, nesse exato momento, muita sorte mesmo, com essa liberdade de ir e vir, esse direito tão simples. O Brasil está agonizando. Meus amigos de infância que ficaram lá, ou fingem uma vida feliz e alienada, ou começam a se engajar numa luta contra o regime militar, tomados por um ódio, por uma violência que não têm, que nunca tiveram (HIDALGO, 2016, p. 46).
\end{abstract}

As opções daqueles que ficaram no Brasil neste período, a alienação ou a luta contra o regime ditatorial, convergem na perda da liberdade, e no "sepultamento da nação e da sua juventude". Entrementes, as vitórias e as derrotas da luta pela libertação do país das garras dos militares aparecem sintetizadas na fala de um conhecido de Maria que consegue informações sobre os acontecimentos do final da década de 1960:

Ciaei [...] contou de um coronel do exército brasileiro que vem cumprindo horário na embaixada do Brasil para vigiar o ir e vir dos exilados em Paris. Contou mais: da beleza que foi a passeata dos Cem Mil no Rio em oposição ao governo militar. Contou muito mais: da invasão da Universidade de Brasília pela polícia e dos estudantes presos com livros de Marx e Lenin; dos alunos que ocuparam a reitoria da Universidade de São Paulo; dos 400 estudantes enfileirados contra o muro da UFRJ no campus da Praia Vermelha e como foram xingados, humilhados, espancados, ameaçados de fuzilamento; da passeata dos mesmo estudantes no dia seguinte, violentamente reprimida, com mortos e feridos; da bomba que a VPR explodiu no quartelgeneral do II Exército, em São Paulo, com débito de um soldado (HIDALGO, 2016, p. 127).

O romance consegue trazer o ambiente de terror da ditadura militar, mesmo sem as personagens estarem inseridas no espaço brasileiro. As incongruências do período autoritário possuem mais força que os discursos historiográficos por serem mediadas pelas personagens que modulam o sofrimento daqueles que viveram este momento terrível. Ao mesmo tempo, o lançamento do romance em 2016, estabelece um vínculo entre o passado da ditadura militar e o impeachment da presidenta Dilma Rousseff, mostrando a potencialidade de se valer do discurso histórico como meio de atuação política e crítica sobre o presente.

O amor dos homens avulsos aborda de maneira lateral a questão da ditadura. Assim, o estado de exceção não é um dos núcleos estruturantes da narrativa, embora apareça em certos pontos dela, levando o narrador a estabelecer algumas descrições deste período. Num primeiro momento, o tempo do poder militar surge como época de felicidade, mas apenas por se tratar da infância do narrador Camilo: "Nem sabíamos quem governava o país. Vivíamos sob a esquisita ditadura da infância: víamos sem enxergar, ouvíamos sem entender, falávamos e não éramos levados a sério. Mas fomos felizes durante o regime" (HERINGER, 2016: 15). Num segundo momento, a repressão militar assassina um amigo de infância do pai de Camilo, fazendo com que o narrador exponha as atrocidades do regime no cotidiano das pessoas:

Um amigo dele tinha morrido. Soluço. Teve que fazer o reconhecimento do corpo. Tanto cadáver papai devia ter na memória de médico, mas aquele o desabou: tiro na nuca, à queima-pele. Cheiro de sangue e cabelo queimado. [...] Era funcionário diminuto de um ministério, amigo seu de infância. Não tinha desafetos nem dívidas, muito menos amante. Meu pai era o único amigo-amigo-mesmo. Esposa inconsolável. Sem filhos. Desovaram o corpo num matagal do Recreio (HERINGER, 2016, p. 55).

Eurídice Figueiredo, no livro A literatura como arquivo da ditadura brasileira, aponta para o número reduzido de escritores que trabalham ficcionalmente com o passado da ditadura militar, se comparado ao número de romances publicados. Apesar de a literatura ser capaz de acolher os mais diversos assuntos, a reflexão sobre o passado das décadas de ditadura militar não é muito desenvolvido pelos autores de ficção:

Na maioria dos casos, os autores que escrevem nos dias de hoje foram afetados, de maneira direta ou indireta, pela ditadura, sendo, em sua maioria, pessoas nascidas nos anos 1940-1950. Note-se, mesmo nos livros publicados entre 2010 e 2016, que poucos autores jovens abordaram a ditadura, como se ela estivesse longe demais, não fizesse parte do seu passado e não os afetasse. O romancista Ricardo Lísias (nascido em 1975) acusa os escritores de sua geração de serem narcisistas e compactuarem com os discursos das elites conservadoras, não contribuindo para elaborar 
o trauma da ditadura, diferentemente dos autores argentinos. [...] Ele aponta um paradoxo: o sucesso de romances que ficcionalizam a violência urbana, que assombra as classes média e alta, seria a outra face da ausência de punição dos culpados pelas atrocidades cometidas durante a ditadura (FIGUEIREDO, 2017, p. 42).

Por este ponto de vista, a literatura que desenvolve a temática da violência urbana seria a expressão do esquecimento de repensar criticamente o passado ditatorial. No entanto, alguns exemplos de romances que trabalham a questão dos tempos da ditadura militar, como Rio-Paris-Rio, colaboram para que este imenso trauma da história brasileira comece a ser passado a limpo.

Outro aspecto trabalhado na narrativa brasileira contemporânea é a carga traumática de um passado que pode ser chamado de ancestral. Esta temporalidade pode acabar pesando sobre os seus supostos herdeiros, como Julius de $O$ inverno e depois (2016), de Luiz Antonio de Assis Brasil, que busca de todas as maneiras apagar qualquer contato com a ancestralidade da sua família possuídora de raízes na antiga nobreza do pampa gaúcho. Assim, a recusa ao passado com origens míticas aparece já no começo do romance, na resistência por parte de Julius em rever as terras da família:

A estância Júpiter, intacta em meio aos tumultos da vida era, contudo, uma imagem cada vez mais vaga, mas ele nunca insistiu em tê-la muito presente; ela que ficasse lá, como um refúgio disponível, com aquele fogo imortal aceso pelo antepassado famoso, que arde no galpão há 150 anos e não se pode apagar sob pena do fim do mundo (ASSIS BRASIL, 2016, p. 30).

O sentimento de não pertença a um mundo de lendas, tradições e rigores patriarcais desconcerta Julius, pois "embora todas as pessoas e documentos digam que tudo isto é metade seu, o campo, a casa, o gado, o galpão [...], este lugar pertence a uma genealogia na qual ele foi incluído pelo acaso" (ASSIS BRASIL, 2016, p. 186). Por conta disto, Julius encara com ironia ações como sentar-se à mesa no lugar que era ocupado pelo seu pai. Este descompasso entre a personagem e uma possível ancestralidade presente no território do pampa gaúcho chega a atrapalhar os seus ensaios de violoncelo, motivo pelo qual Julius busca o isolamento da estância Júpiter.

Outro elemento na construção narrativa que alude para a hierarquia proveniente da ancestralidade é a presença do passado evocada pelo quadro representando o Visconde, antepassado de Julius. A opressão do passado familiar é tamanha sobre ele, que quando a sua irmã retira o quadro da parede, o violoncelista sente um imenso alívio:
Só agora ele percebe que há um vazio branquicento, quadrangular, onde estava o retrato do visconde.

$\mathrm{O}$ que aconteceu com o retrato que estava ali?

A Antônia o tirou e escondeu. Ela sempre faz isso quando chega na estância. Antes de ir embora ela põe de novo no lugar.

Ele não pode evitar uma constatação: a sala e toda a estância ficaram leves sem a esmagadora opressão do retrato. Por que se deixara massacrar até hoje por aquela presença? Insultar o antepassado não resolve nada. Tão simples, tirar o retrato da parede (ASSIS BRASIL, 2016, p. 262).

Livre do olhar do visconde, que faz Julius lembrar a possibilidade de pertença a uma genealogia que deita raízes num passado ancestral, a sua vida readquire uma leveza: o trauma perde a sua força pelo esquecimento. Em contrapartida, os outros romances analisados nesta sessão buscam trazer à tona o passado histórico. Assim, Ponciá Vicêncio revisita criticamente a escravidão e os seus desdobramentos na sociedade brasileira, na tentativa de disseminar nos leitores a consciência da condição vilipendiada da população afro-brasileira. Também a busca pela passagem a limpo do trauma da ditadura é um dos eixos estruturantes de Rio-Paris-Rio, romance que almeja expor os desmandos do período militar.

\section{Todos pertencem à história}

A condição proteica da literatura permite que seja possível tanto escrever ficcionalmente sobre uma personalidade de renome da cultura brasileira, quanto sobre alguém que compõe a massa de anônimos. O que une ambos os casos é o pertencimento à história nacional, afinal, desde a École des Annales, sobretudo com o advento da história das mentalidades, é reconhecido o valor epistemológico para a historiografia da população que não interfere diretamente nas decisões políticas ou econômicas de um país. Isto posto, esta sessão estudará dois romances sob perspectivas diversas da escrita do passado: Machado (2016), de Silviano Santiago, e A vida invisível de Eurídice Gusmão (2016), de Martha Batalha.

Um profundo conhecimento histórico, uma vasta documentação, que é inclusive apresentada ao leitor através de fotos de época e de scans de material de arquivo, além de um arguto senso da potencialidade da fabulação, valendo-se de acontecimentos verídicos, acabam resultando num romance como Machado, tão pertinente ou mais para a compreensão do passado nacional, quanto um livro historiográfico.

Uma das propostas de Silviano Santiago ao romancear a vida do escritor Machado de Assis é expor criticamente o que foi a passagem do Império para a República, sobretudo focalizando a modernização do Rio 
de Janeiro, na primeira década do século XX. O tom do narrador, que se confunde com a voz do eu-autoral, é de descrença no que diz respeito à europeização da então capital nacional. A desconfiança relativa ao progresso "a toque de caixa" é uma das opiniões mais recorrentes ao longo deste romance, fazendo com que a famosa ironia machadiana, seja também a de Silviano Santiago.

A postura de descrença face à modernização à la parisienne do Rio de Janeiro aparece em vários trechos, como neste em que é ironizada a postura republicana: "Estamos corrigindo, dizem os novos donos do poder, o imperdoável atraso histórico da nação" (SANTIAGO, 2016, p. 39). Deste modo, o descompasso existente entre o Brasil e a Europa é visto como uma vergonha para a nova classe dirigente, demandando ações que deveriam, o mais rápido possível, transformar o Rio de Janeiro numa cidade europeia. Emblema desta "modernização" é a construção da avenida Central, durante o mandato presidencial de Rodrigues Alves e do prefeito Pereira Passos. A descrição do processo de abertura da avenida é feita na confluência da exatidão dos historiadores e da liberdade metafórica e irônica do romancista:

A magnífica avenida Central. Em construção desde o dia 8 de março de 1904 , com trinta e três metros de largura e mil e oitocentos de comprimento, ela se estende pelo centro da capital federal qual gigante adormecido, deitado em berço esplêndido. [...] A longa avenida Central se abre e se fecha por dois obeliscos plantados nos extremos, assim como na praça da Concórdia, em Paris, [obelisco] que tinha guarnecido o palácio do rei Ramsés II em Tebas e fora doado pelo vice-rei do Egito, Mehmet Ali, à capital da França. "Esse obelisco que hoje se ergue à beira-mar da cidade do Rio de Janeiro, no término da mais famosa obra do governo Rodrigues Alves", escreve a revista Kosmos, "não tem esses antecedentes gloriosos, não veio do solo africano, não o cobrem estranhos hieróglifos misteriosos, não o produziu o braço escravo, não foi regado com as lágrimas do oprimido" (SANTIAGO, 2016, p. 78).

A presença de dados pontuais, como o dia do início da construção da avenida Central e as suas dimensões físicas, coincidem com a veracidade almejada pelo discurso histórico; por outro lado, a liberdade criativa de comparar metaforicamente a nova avenida com um "gigante adormecido, deitado em berço esplêndido" pende para o campo da criação artística. A mistura de procedimentos escriturais parece levar em conta a porosidade existente entre os campos da literatura e da história, por ambos lidarem com técnicas narrativas para a sua configuração textual. A exploração desta potencialidade para a transmissão de conhecimento mostra quanto a história tem a ganhar ao se transformar também num "gênero anfíbio", levando em conta os processos criacionais da literatura.

No campo da história, exemplo do uso de elementos inicialmente próprios ao discurso da literatura, para a escrita historiográfica é o livro Os bestializados: o Rio de Janeiro e a República que não foi, de José Murilo de Carvalho. O trecho a seguir mostra como a incorporação de subsídios encontrados mais comumente na configuração de textos literários não faz com que o discurso da história perca força epistemológica:

Domesticada politicamente, reduzido seu peso político pela consolidação do sistema oligárquico de dominação, à cidade pôde ser dado o papel de cartãopostal da República. Entrou-se de cheio no espírito francês da belle époque, que teve seu auge na primeira década do século. $O$ entusiasmo pelas coisas americanas limitara-se às fórmulas políticas. $\mathrm{O}$ brilho republicano expressou- se em fórmulas europeias, principalmente parisienses. Mais do que nunca, o mundo literário voltou-se para Paris, os poetas sonhavam viver em Paris e, sobretudo, morrer em Paris. [...] Ao visitar [o Rio de Janeiro], uma poetisa francesa, entusiasmada, escreveria um livro de poemas com o título La Ville Merveilleuse. Vindo de uma francesa, era a glória, e compensava o epíteto depreciativo de rastaqueras que em Paris era dado aos brasileiros (CARVALHO, 1987, p. 39).

O uso da ironia pelo historiador quebra a rigidez que faz cansativa a leitura de um escrito historiográfico possuidor de um viés mais nomológico, deixando o discurso da história mais prazeroso, sem, no entanto, perder a sua força epistemológica. O mesmo vale para a inserção do humor, ao relatar o caso da suposta glória republicana através da publicação de um livro de uma poetisa francesa. De maneira semelhante, Silviano Santiago também adotou uma postura irônico-humorística para expor como a modernização nacional passou pela prescrição de condutas que não necessariamente significam "civilização":

Após seis meses de trabalho insano, o espaço a ser ocupado pela avenida Central e adjacências é terra batida e nuvens de poeira a céu aberto. Na capital federal que se civiliza, já não se cospe dentro dos bondes, embora ainda se cuspa na rua. O uso do paletó é obrigatório no centro da cidade. Nada de meia rota, suja e suada. Por que descalços os pés, se há tamancos a todos os preços? Ninguém na Europa sai à rua em pés no chão e vestido em mangas de camisa (SANTIAGO, 2016, p. 82).

O conhecimento do passado não diminui com a adoção de procedimentos desviantes de uma escrita da história mais tradicional. Pelo contrário, o acesso ao saber 
histórico torna-se mais palatável a um maior número de leitores, fazendo com que o conhecimento possa ser mais amplamente ativado.

Outra proposta do romance de Silviano Santiago consiste na ficcionalização de uma personalidade histórica: o escritor Machado de Assis. Este tipo de procedimento metaliterário é recorrente na contemporaneidade, principalmente sob dois formatos: "engenhosos exercícios metaficcionais convidam a problematizar vários aspetos da narrativa em função da figura do escritor inscrito na ficção, seja ele uma pura figura ficcional, seja ele uma projeção metaléptica do escritor real" (REIS, 2012, p. 19). No entanto, o romance Machado consiste num caso especial que busca dar conta das duas formas de exercício metaficcional. Assim, o narrador Silviano Santiago estabelece a união entre o "mímico do Cosme Velho" e ele próprio, conectando também o passado ao presente:

Somos Machado \& eu semelhantes ao deus bifronte romano Jano, que emprestou o nome ao mês de janeiro no calendário cristão e à colina do Janículo lá em Roma. É Jano quem, no dia 1을 de janeiro, vela pelas transições e tutela os finais e as entradas de ano. Machado \& eu somos duas faces diferentes, impressas numa moeda ainda desprovida de valor simbólico. A escapada do passado em direção ao futuro, ou a viagem do futuro em busca do passado, transfigurará aos dois na cara de uma moeda única chamada Literatura. Duas caras, uma só coroa (SANTIAGO, 2016, p. 57).

A admiração ao escritor Machado de Assis desencadeou um processo de transfiguração em que Silviano Santiago busca ser outro, sendo ele próprio, "dois corpos, uma só imagem". Foi por conta da leitura intensa da obra literária do escritor carioca que é desenvolvida uma metamorfose no eu-narrativo, evidenciando o imenso poder da literatura: quem lê, inevitavelmente, acaba o livro sendo outro, podendo assimilar o que foi lido. Portanto, "em busca de novos rumos [para a literatura, os] ficcionistas atuais olham, com uma nostalgia que não os paralisa, para seus antepassados, cujas vidas e obras eles revitalizam em livros que trazem a marca de nosso tempo" (PERRONE-MOISÉS, 2016, p. 147).

Machado traz como personagem principal um romancista de reconhecido valor histórico, tendo por pano de fundo acontecimentos que aparecem em discursos historiográficos "canônicos" por se tratarem de fatos públicos, como a europeização do Rio de Janeiro no começo do século XX. Por outro lado, $A$ vida invisivel de Eurídice Gusmão, apresenta como personagem central uma "pessoa comum", levando a sua "vida invisível", como alude o titulo do romance, que seria desprezada pelo discurso historiográfico se não houvesse ocorrido uma revitalização do seu objeto de estudo pela École des
Annales. O reconhecimento do valor epistemológico dos acontecimentos cotidianos pela história das mentalidades faz com que o romance de Martha Batalha possa ser compreendido também como um relato histórico.

A acoplagem ao estudo da história de outras ciências, como a sociologia das ideologias, a antropologia, a psicanálise e a semântica estrutural possibilitou o surgimento da história das mentalidades. Esta vertente da historiografia privilegia os modos de pensar e agir coletivos, ajustando-se a necessidade de explicar os elementos que mais profundamente persistem dentro de uma determinada sociedade. Como explica Paul Ricœur, o homem comum é o objeto de estudo da história das mentalidades:

L'écoute des idéologies, de l'inconscient collectif des parlers spontanés confère à l'histoire un sens de l'étrangeté, de la distance et de la différence comparable à celui qui donnait tout à l'heure le regard de l'anthropologue. C'est encore l'homme quotidien, bien souvent privé de la parole à travers l'histoire. Cette modalité de rationalité historique marque en même temps l'effort le plus intéressant pour porter le quantitatif au troisiéme niveau, celui des attitudes à l'égard du sexe, de l'amour, de la mort, du discours parlé ou écrit, des idéologies et des religions (RICEEUR, 1983, p. 197).

Assim, a história das mentalidades passa necessariamente pela elaboração de um sistema plausível compreendendo representações de imagens, mitos, ideias, práticas estáveis de uma dada sociedade. O historiador delimita a sistematização que pretende configurar, privilegiando os aspectos do cotidiano que garantam força para a sua proposta de trabalho. Como a história das mentalidades tem por objeto o homem cotidiano, as mais variadas marcas do passado podem ser estabilizadas em sistema. Por conta disto, que uma cena da vida cotidiana da metade do século XX, configurada no romance de Martha Batalha, pode contribuir para que uma página da história brasileira não caia no esquecimento:

Um dia antes do jantar ela foi ao aviário comprar o peru. Voltou para casa segurando o animal e com Zélia vendo a cena indignada, porque ainda não era Natal. Eurídice soltou o peru no pátio e foi preparar a cuia com cachaça que daria ao bicho antes de matá-lo. O álcool deixaria o peru tranquilo, e a carne macia. Depois de fechar o armário de bebidas permaneceu apoiada no móvel por alguns segundos. Seu caderno de receitas era um livro pronto; ela queria publicá-lo, e quem sabe fazer outro em seguida. Eurídice poderia ter um programa culinário na rádio, poderia assinar uma página no Jornal das Moças! Poderia abrir um curso de forno e fogão para mocinhas recém-casadas. Seus olhos grandes ficaram maiores (BATALHA, 2016, p. 30). 
Neste trecho, evidencia-se uma série de questões envolvendo práticas do cotidiano carioca da metade do século XX. Naquela época, comprava-se peru nos aviários e não como hoje congelado no supermercado; o programa culinário era atração do rádio, já hoje é transmitido na televisão; Eurídice queria assinar uma página no Jornal das Moças, se fosse nos tempos atuais, provavelmente criaria um blog na internet. O romance de Martha Batalha oferece com densidade uma série de práticas datadas historicamente, que num contraste com outros tempos históricos, fornece subsídios capazes de caracterizar o período da metade do século XX. Assim, "c'est effectivement l'historien [des mentalités] qui est intéressé par la transformation des structures, soit sous la pression des changements dans les conditions matérielles et dans les relation vécues, soit à la faveur des conflits et des contestations" (RICEUR, 1983, p. 197).

A pesquisa dos hábitos e dos pensamentos da época foi fundamental para a construção de um romance verossímil. Um exemplo desta investigação encontra-se no papel do rádio dentro do romance. Assim, o marido de Zélia, a vizinha bisbilhoteira, não faz nada além de escutar o rádio; Antenor, marido de Eurídice, não gosta de ser incomodado enquanto escuta suas emissões; já Guida, sua irmã, fica repetindo a expressão "almofadas salmão", porque tinha acabado de ouvir num programa. Além disso, na casa de Eurídice, escutar a Rádio Nacional é prática frequente, como está evidenciado no seguinte trecho: "o final daquela noite não foi diferente do final de qualquer outra. Mãe e filha retiraram os pratos da mesa, enquanto Antenor e Afonso foram para a sala ouvir a Rádio Nacional" (BATALHA, 2016, p. 32). $\mathrm{O}$ uso do rádio consistiu numa dinâmica marcante do cotidiano da década de 50, como bem aponta Eliane de Freitas Dutra:

\footnotetext{
A Rádio Nacional sobreviveu ao Estado Novo, sendo líder de audiência e entrando na intimidade dos lares brasileiros ao longo da década de 1950 até os anos 1960. O rádio com veículo de cultura, de educação e de entretenimento foi objeto de investimentos bastante diversificados. [...] Para se ter uma ideia da extensão do aparato [do sistema radiofônico], é suficiente lembrar que os Diários Associados, o grande conglomerado de comunicações que dominaria o Brasil até os anos 1970, possuía, nos anos 1930, um total de 35 emissoras de rádio, entre elas as famosas Rádio Tupi e Tamoio que, ao lado da Rádio Globo e das estatais Rádio Nacional e Rádio do Ministério da Educação, difundiam programas destinados a um público de gosto e interesses variados e também produções de diferentes agentes oriundos do meio artístico e cultural (DUTRA, 2013, p. 260).
}

Portanto, seja na configuração ficcional de fatos públicos, seja na construção narrativa de acontecimentos privados, a literatura dialoga com a história. A leitura proposta para o romance Machado possibilitou perceber como a ficcionalização de eventos da história pública não resulta na perda de sua força epistemológica. Já a leitura de A vida invisivel de Eurídice Gusmão possibilita conhecer práticas e pensamentos do cotidiano de pessoas comuns, que, sem dúvidas, fazem parte da história.

\section{Escrever o presente: a literatura como história do tempo contemporâneo}

A ambientação temporal da literatura brasileira contemporânea nas décadas finais do século XX e nas iniciais do século XXI pode representar a antecipação de algumas reflexões, que posteriormente integrarão os livros de história. Esta capacidade de configurar o presente nas suas múltiplas representações é uma capacidade da literatura, que aceita no seu discurso uma variedade praticamente infinita de temas possíveis. Nesta terceira parte do trabalho, buscarei elementos representativos da contemporaneidade temporal em três romances que possuem parte ou a totalidade do seu enredo num passado que é quase presente: $O$ tribunal da quinta-feira (2016), de Michel Laub, O amor dos homens avulsos (2016), de Victor Heringer, e Correr com rinocerontes (2016), de Cristiano Baldi.

O romance $O$ tribunal da quinta-feira traz a narração de como a publicação na internet de uma série de mensagens portadoras de conteúdo machista e homofóbico provocou uma reviravolta na vida do autor delas, José Victor, que é o narrador do romance. Quem realiza a divulgação do conteúdo é Teca, a ex-namorada do narrador, que, ao descobrir as mensagens, não titubeia e as disponibiliza na internet para acusar José Victor do seu comportamento desprezível. Entretanto, pelo romance estar estruturado no discurso do narrador, José Victor, há sempre a tentativa de buscar a absolvição frente ao leitor, sendo a narrativa uma série de esforços retóricos para ganhar a sua confiança. Esta estratégia discursiva é construída através de um texto que prima pela ambiguidade, privilegiando a omissão de fatos, tendo em vista a busca pela simpatia do leitor.

A internet como um tribunal é uma característica do tempo contemporâneo e o fato de Michel Laub ter configurado narrativamente tal tema é um dos pontos fortes do romance. Apesar de o narrador procurar convencer o leitor a todo tempo da sua inocência, quando a sua trajetória existencial atinge o seu ponto mais baixo, despedido do emprego e sem saber se conta com o apoio da sua nova namorada, José Victor não consegue mais 
esconder a sua verdadeira essência e se revela abertamente como alguém patético:

Eu caminhei devagar entre as baias, duzentos e trinta funcionários que pareciam estar olhando para mim, as pessoas andando na avenida Berrini sem saber que na janela daquele décimo quarto andar há alguém que simboliza o que deve ser condenado e esquecido, o resumo de uma carreira forjada por valores que ficaram para trás na marcha da história e da cultura, um homem branco, de orientação afetiva patriarcal, com humor baseado na depreciação e objetificação de grupos discriminados ao longo de séculos e milênios, cuja queda se tornou ainda mais patética quando o primeiro post sobre o caso foi publicado nas redes (LAUB, 2016, p. 158).

A busca pela ambiguidade narrativa, privilegiando os não-ditos a um discurso claro, pode fazer com que o leitor se perca nas artimanhas do narrador. O tribunal $d a$ quinta-feira ao utilizar deste expediente para a construção do discurso literário pode desencadear pelo menos dois tipos de recepção: 1) o leitor toma consciência de quem é o narrador, um sujeito egoísta e misógino, podendo assim melhor lidar com tais tipos no seu presente histórico, ou 2) a leitura não atinge o ponto de reconhecer o caráter antiético do narrador, fazendo com que a experiência estética não atinja toda a sua potencialidade. Portanto, a criação de um discurso literário ambíguo necessita de leitores competentes para que a narrativa consiga mudar a relação do leitor com a sua realidade, caso contrário a leitura não ativará toda a potencialidade do romance. Em vista deste fator que Karl Erik Schølhammer discute o efeito da "agoridade":

Ao exigir o presente e lançar mão da "agoridade" do presente estético, Lyotard viu na arte e na literatura uma potência que, em vez de abrir como a moderna promessa de uma utopia radical no horizonte da história, se faz presente no instante da experiência afetiva como pura possibilidade de mudança na relação entre o sujeito e sua realidade e, simultaneamente, como ameaça de que nada vai acontecer (SCHØLLHAMMER, 2009, p. 12).

Se o leitor não conseguir reconhecer o perfil antiético do narrador, o romance corre a ameaça de pouco mudar a sua perspectiva junto à existência. Por outro lado, uma leitura proficiente possibilitará a "mudança da relação entre o sujeito e sua realidade". Esta ambivalência pode ser considerada uma marca da literatura contemporânea, que não se preocupa em deixar todo o seu enredo explicado, forçando o seu leitor a buscar um sentido suplementar nas omissões do narrador.
No romance de Michel Laub, uma marca dos tempos contemporâneos emerge no tribunal gerado pela divulgação do conteúdo de mensagens privadas na rede de computadores. Já em $O$ amor dos homens avulsos, a banalização da violência aparece como traço qualificativo do nosso tempo histórico. A recorrência de crimes nas grandes cidades fez com a sociedade em geral se tornasse indiferente para a tristeza de tais acontecimentos. Provavelmente, o nosso tempo será compreendido como de uma extrema insensibilidade devido à vulgarização da violência. Num trecho do romance de Victor Heringer é mostrado de modo exemplar este aspecto de apatia diante de fatos terríveis, como o desaparecimento das pessoas:

E se eu tomasse um táxi que me deixasse na entrada do shopping? As portas se abririam automaticamente, o bafo do ar condicionado me convidaria a entrar. E se eu entrasse, para ver como os clientes estão reagindo ao sumiço do garoto? O chão de granito refletiria as luzes fluorescentes, como se encapado com uma película de plástico. Neon. Os mesmos letreiros que há em toda a parte, os mesmos cheiros de qualquer praça de alimentação, dos shoppings do Leblon aos de Costa Barros. O pé-direito alto ecoaria passos e risadas e conversas. Somem tantas pessoas anualmente numa cidade como o Rio de Janeiro. Quem se importa...? Essa moça que vai subindo a escada rolante, de calça de ginástica lilás: ela não se importa. A quarentona orgulhosamente solteira namorando sapatos na vitrine não se importa. O pai que prova a amostra grátis do perfume com o seu filho não se importa. $\mathrm{O}$ filho, assim que entrar no ensino médio, também não vai mais se importar, nem com as crianças que desaparecem, nem com a Amazônia, nem com o ozônio, nem com nada (HERINGER, 2016, p. 79).

A construção narrativa com a recuperação anafórica da estrutura "não se importa" representa a banalização da violência na sociedade brasileira contemporânea. $\mathrm{O}$ narrador Camilo, extremamente cético quanto à possibilidade de qualquer mudança desta indiferença na busca por qualquer tentativa de resolução dos problemas da humanidade, acaba estendendo a impassibilidade existencial à forma de encarar todas as coisas. O ser humano que vive o tempo presente seria um completo apático. No entanto, esta postura de descrença do narrador face à humanidade deve ser matizada, pois é decorrente, sobretudo da morte do seu amor, Cosme, tragédia que Camilo não supera, fazendo com que o livro tenha um teor extremamente depressivo.

Sinal desta disforia está estruturalmente evidenciado na contagem dos capítulos passar de progressiva para regressiva após a narração do assassinato de Cosme. Este acontecimento traumático coloca Camilo 
num estado de tristeza que não é superado: "O assassinato tomou domínio de mim para o resto da vida. Fui colonizado" (HERINGER, 201, p. 114). A perda de um sentido para a vida é conceitualmente caracterizada como "quête" por Susana Scramim: "É interessante pensar a literatura do presente com os procedimentos da 'busca', ou seja, da 'quête', no lugar da aventura. Na 'quête' sobrevive uma noção de abandono do 'projeto"" (SCRAMIM, 2007, p.19). Este abandono do projeto existencial pode resultar num fim catastrófico para o ser em estado de deriva.

Em Correr com rinocerontes, romance que se passa na década de 1990, na cidade de Porto Alegre, $\mathrm{o}$ narrador e personagem principal (não nomeado) assume um tom cáustico para expor uma sociedade com duvidosos valores éticos. O uso recorrente do humor não afasta um sentimento de urgência para expor a hipocrisia da classe dominante brasileira, pelo contrário, a ironia reforça a tragédia que é viver nos tempos contemporâneos em que o culto à futilidade é traço marcante da sociedade.

Exemplo da intenção do narrador em desvelar a precariedade existencial da elite brasileira pode ser encontrado no seguinte trecho, em que há o deboche em relação à busca imoderada da beleza, mesmo que falsa: "Gente demais, perto demais, rica demais. Esposas muito turbulentas, que revolviam a multidão, com uns três quilos de base no rosto, repuxadas como queimaduras" (BALDI, 2017, p.57). Ou então o caráter fútil da alta sociedade aparece em trechos de um sarcasmo mordaz, em que práticas de ostentação da riqueza são comparadas a prêmios que reconhecem contribuições notáveis à humanidade: "Alguém abriu uma garrafa de champanhe e foi aplaudido como se ganhasse o Nobel" (BALDI, 2017, p. 72). Além disso, um lado pífio da universidade contemporânea também não escapa à ironia do narrador de Correr com rinocerontes:

Minha mãe vinha comentando como um grupo multidisciplinar da universidade passou mais de seis anos estudando o comportamento do lobo-guará. Tudo, segundo ela, havia se tornado multidisciplinar. Era impossível conseguir algum dinheiro se o seu projeto não tivesse o suporte de pelos menos três áreas do conhecimento. Quanto mais esdrúxula fosse a combinação, tanto melhor. Se você pudesse juntar Arquitetura, Neurobiologia e Direito em um só projeto, então pronto. Lá estava a sua chance de formar um grupo de pesquisa com dez alunos da graduação, sete da pós-graduação, duas salas grandes com ar-condicionado (BALDI, 2017, p. 127).
A perda da confiança na universidade como espaço próprio para um contato eficiente com o conhecimento é outro questionamento proposto pelo narrador deste romance. Assim, alguns traços marcantes na representação ficcional do tempo histórico do final do século XX foram levantados. Os aportes de Correr com rinocerontes na sistematização de uma sociedade sem valores éticos responsáveis, deslumbrada com o poder da riqueza, egocêntrica e narcísica, podem ser considerados como contribuições para o melhor entendimento do tempo em que vivemos.

Os romances que lidam com um passado que é quase o presente desenvolvem o tempo histórico de uma maneira peculiar, pois não estão amparados por discursos historiográficos ou pesquisas de arquivos. Logo, o escritor parte da sua percepção do que é marcante no tempo que o envolve, e que vai sendo ficcionalmente configurado. Deste modo, nos três romances aqui analisados foram encontradas questões que estão latentes nos tempos atuais: o poder social da internet, a banalização da violência e o culto à futilidade.

\section{Referências}

ASSIS BRASIL, Luiz Antonio. O inverno e depois. Porto Alegre: L\&PM, 2016.

BALDI, Cristiano. Correr com rinocerontes. Porto Alegre: Não Editora, 2017.

BATALHA, Martha. A vida invisivel de Eurídice Gusmão. São Paulo: Companhia das Letras, 2016.

CARVALHO, José Murilo de. Os bestializados: o Rio de Janeiro e a República que não foi. São Paulo: Companhia das Letras, 1987.

DUTRA, Eliana de Freitas. Cultura. In: GOMES, Angela de Castro (Coord.). História do Brasil Nação. Vol. 4. Olhando para dentro (1930-1964). Madri e Rio de Janeiro: Fundación Mapfre e Editora Objetiva, 2013.

EVARISTO, Conceição. Ponciá Vicêncio. Rio de Janeiro: Pallas, 2017.

FIGUEIREDO, Eurídice. A literatura como arquivo da ditadura brasileira. Rio de Janeiro: 7 Letras, 2017.

HERINGER, Victor. O amor dos homens avulsos. São Paulo: Companhia das Letras, 2016.

HIDALGO, Luciana. Rio-Paris-Rio. Rio de Janeiro: Rocco, 2016.

LAUB, Michel. O tribunal da quinta-feira. São Paulo: Companhia das Letras, 2016.

LOWENTHAL, David. Como conhecemos o passado. In: Projeto História, n. 17, p. 63-201, 1998.

PERRONE-MOISÉS, Leyla. Mutações da literatura no século XXI. São Paulo: Companhia das Letras, 2016. 
REIS, Carlos. História literária e personagens da história: os mártires da literatura. In: MOREIRA, Maria Eunice (Org.). Percursos críticos em história da literatura. Porto Alegre: Libretos, 2012.

RICEUR, Paul. Temps et récit. Tome I: L'intrigue et le récit historique. Paris: Seuil, 1983.

SANTIAGO, Silviano. Machado. São Paulo: Companhia das Letras, 2016. SCHØLLHAMMER, Karl Eric. Ficção brasileira contemporânea. Rio de Janeiro: Civilização Brasileira, 2009.

SCRAMIM, Susana. Literatura do presente: história e anacronismo de textos. Chapecó: Argos, 2007.
SILVA, Assunção Maria de Souza e. Ponciá Vicêncio, memórias do eu rasurado. In: Alguma prosa. DEALTRY, Giovanna (Org.). Rio de Janeito: 7 Letras, 2007.

Autor:

MATEus RoBAsKi TIMM

Pontifícia Universidade Católica do Rio Grande do Sul.

Porto Alegre, RS, Brasil.

mateustimm@outlook.com

Recebido: $15 / 08 / 2018$

Aprovado: $15 / 08 / 2018$ 